\title{
ABUNDANCE AND CHARACTERIZATION OF COWPEA MISCELLANY RHIZOBIUM FROM SUDANESE SOILS
}

\author{
M. A. HADAD and T. E. LoYNachan \\ Department of Agronomy, Iowa State University, Ames, IA 50011, U.S.A.
}

(Accepted 30 January 1985)

\begin{abstract}
Summary-Sudan is the fourth largest exporter of groundnuts in the world, yet little is known concerning the plant-rhizobial symbiosis. A study was made on the abundance of groundnut-nodulating rhizobia in the soils of Sudan as related to soil properties and the duration since groundnuts were last planted. Also, physiological, serological and nitrogen-fixing characteristics of Sudanese rhizobia are reported. All but one of 32 sites contained more than 300 rhizobia $\mathrm{g}^{-1}$ soil capable of forming nodules on siratro (Macroptilium atropurpureum). Several of these soils had never been planted to groundnut. A correlation matrix indicated no relationship was present between soil rhizobial populations and any of the measured soil properties, or between soil rhizobial populations and the time since groundnuts were last planted in the rotation. Individual isolates of Rhizobium from six legumes: groundnut (Arachis hypogaea), mung bean (Vigna radiata), lubia (Dolichos lablab), cowpea (Vigna unguiculata), pigeonpea (Cajanus cajan) and bambara groundnut (Voandzeia subterranea) were obtained from four locations in Sudan. All isolates were able to nodulate each of the six legumes when grown in sterile vermiculite. The isolates grew in $0.1 \%$ $\mathrm{NaCl}$-amended media, but growth was variable in $2.0 \%$ amended media. Most isolates grew after exposure to moist heat for $15 \mathrm{~min}$ at $50^{\circ} \mathrm{C}$. Optimum $\mathrm{pH}$ for growth was, in general, between $\mathrm{pH} 6$ and 8 . Agglutination reactions indicated isolates from groundnuts, as well as isolates from other legumes, belonged to several serological groupings. Some isolates formed a large number of nodules on a Sudanese groundnut cultivar, whereas other isolates formed only few nodules.
\end{abstract}

\section{INTRODUCTION}

Rhizobium strains with little symbiotic specificity are more common in the tropics than in temperate regions of the world. Groundnut (Arachis hypogaea L.), which is an important food legume in several developing countries, is nodulated by members of the cowpea miscellany (Fred et al., 1932; Buchanan and Gibson, 1974). This large heterogeneous group of rhizobia is characterized by a high degree of symbiotic promiscuity, and members are thought to be slow growing and alkaline producing. Some inconsistencies, however, were reported in Sudan by Habish

- and Kheiri (1968), who claimed that their groundnut Rhizobium isolates were fast growing and acid producing. Furthermore, their isolates did not nodulate cowpea, which is not characteristic of the cowpea group. Elsewhere, several strains of fast-growing rhizobia capable of nodulating cowpea and soybean have been reported (Zablotowicz and Focht, 1981). These findings emphasize that further work is needed in classifying rhizobia of the tropics.

The distribution of Rhizobium strains has been shown to vary with soil pH (Damirgi et al., 1967), temperature (Ahmed et al., 1981), available and organic nitrogen (Bezdicek, 1972) and with the frequency of occurrence of soybeans in crop rotations (Weaver et al., 1972). Only limited research, however, has been conducted on the effect of such soil factors on groundnut-nodulating rhizobia, especially in the tropics.

Rhizobia vary in effectiveness in fixing atmospheric nitrogen. Tropical rhizobia may nodulate crops readily but may not supply all the required nitrogen for maximum yields (Nambiar and Dart, 1982). Gathering basic information concerning cowpea-type rhizobia may help in identifying the factors that limit the legume-Rhizobium symbiosis. Accordingly, this work was conducted to:

(1) assess abundance of cowpea-type rhizobia in different production regions of Sudan and correlate the data to soil properties and the place of groundnuts in crop rotations;

(2) obtain Rhizobium isolates from fresh nodules of the commonly grown legumes in Sudan and study their growth and serological characteristics. Test under greenhouse conditions the infectivity and effectiveness in nitrogen fixation of the isolates with a cultivar of groundnut from Sudan.

\section{MATERIALS AND METHODS}

\section{Soils and Rhizobium abundance}

In June 1980, 32 sites in Sudan of varying soil types and management practices were sampled at the beginning of the rainy season (Table 1). The sites were chosen in geographical regions with existing groundnut production (central and south central Sudan) and with potential groundnut expansion (western Sudan, considered west of the Nile River; see Fig. 1). Three subsamples from each site were randomly taken from a 0- to 15-cm depth. Moisture and rhizobial numbers were determined within $24 \mathrm{~h}$ after sampling, and the rest of the soil samples were dried, crushed, sieved ( $<3 \mathrm{~mm}$ ), and thoroughly mixed before chemical analyses were made.

Rhizobium numbers were determined in growth pouches (Weaver and Frederick, 1972) by using the MPN-technique (Vincent, 1970) with siratro (Macroptilium atropurpureum) as the test plant. Ten $\mathrm{g}$ of each soil was added to $90 \mathrm{ml}$ of sterile tapwater in 
Table 1. Soil characteristics ${ }^{\mathrm{a}}$ of the survey locations in Sudan

\begin{tabular}{|c|c|c|c|c|c|c|c|c|}
\hline \multirow[b]{3}{*}{ Soil } & \multirow[b]{3}{*}{ Location } & \multirow{3}{*}{$\begin{array}{c}\text { Moisture } \\
(\%)\end{array}$} & \multirow{2}{*}{\multicolumn{2}{|c|}{$\mathrm{pH}$}} & \multicolumn{2}{|c|}{ Organic } & \multirow{3}{*}{$\begin{array}{c}\text { Rhizobium }^{\mathrm{b}} \\
\text { No. } \\
\left(\text { No. } \mathrm{g}^{-1}\right)\end{array}$} & \multirow[b]{3}{*}{ Years } \\
\hline & & & & & & & & \\
\hline & & & Suspension & Paste & $(\%)$ & $\left(\mu \mathrm{g} \mathrm{g}^{-1}\right)$ & & \\
\hline 1 & Abu Naama & 9.89 & 8.2 & 7.0 & 0.431 & 599 & $1.1 \times 10^{4}$ & 1 \\
\hline 2 & Abu Naama & 10.13 & 8.9 & 7.9 & 0.463 & 588 & $2.4 \times 10^{6}$ & $\infty^{d}$ \\
\hline 3 & Abu Naama & 10.13 & 8.6 & 7.7 & 0.414 & 613 & $2.9 \times 10^{4}$ & 1 \\
\hline 4 & Abu Naama & 9.65 & 8.8 & 7.8 & 0.406 & 588 & $4.4 \times 10^{4}$ & 1 \\
\hline 5 & Abu Naama & 10.13 & 8.6 & 7.7 & 0.414 & 641 & $1.1 \times 10^{5}$ & 1 \\
\hline 6 & Abu Naama & 10.01 & 8.6 & 7.7 & 0.406 & 616 & $5.3 \times 10^{4}$ & 2 \\
\hline 7 & Abu Naama & 10.13 & 8.8 & 8.0 & 0.431 & 613 & $1.5 \times 10^{4}$ & 1 \\
\hline 8 & Abu Naama & 10.13 & 8.7 & 7.7 & 0.378 & 578 & $4.2 \times 10^{4}$ & 2 \\
\hline 9 & Abu Naama & 10.13 & 8.8 & 7.7 & 0.395 & 588 & $7.5 \times 10^{4}$ & 4 \\
\hline 10 & Abu Naama & 10.01 & 8.8 & 7.7 & 0.378 & 574 & $4.4 \times 10^{4}$ & 3 \\
\hline 11 & Abu Naama & 9.76 & 8.8 & 7.7 & 0.446 & 574 & $1.6 \times 10^{5}$ & 1 \\
\hline 12 & Abu Naama & ND & ND & ND & ND & ND & $1.1 \times 10^{4}$ & $\infty$ \\
\hline 13 & Wad Medani & 9.65 & 8.8 & 7.8 & 0.492 & 616 & $1.1 \times 10^{4}$ & $\infty$ \\
\hline 14 & Wad Medani & 15.20 & 8.6 & 7.9 & 0.481 & 602 & $1.5 \times 10^{4}$ & 2 \\
\hline 15 & Wad Medani & 10.25 & 8.9 & 8.0 & 0.492 & 630 & $2.0 \times 10^{4}$ & 1 \\
\hline 16 & Wad Medani & 6.26 & 9.0 & 8.0 & 0.424 & 574 & $3.5 \times 10^{4}$ & 3 \\
\hline 17 & Wad Medani & 6.38 & 9.0 & 8.5 & 0.460 & 564 & $3.5 \times 10^{4}$ & 2 \\
\hline 18 & Wad Medani & 7.52 & 8.7 & 7.9 & 0.427 & 588 & $2.1 \times 10^{4}$ & 4 \\
\hline 19 & Wad Medani & 6.04 & $\begin{array}{l}0.1 \\
8.6\end{array}$ & 8.0 & 0.416 & 602 & $7.3 \times 10^{4}$ & 1 \\
\hline 20 & Sennar & 6.49 & 8.4 & 7.8 & 0.378 & 560 & $1.5 \times 10^{4}$ & 3 \\
\hline 21 & Sennar & 9.52 & 8.5 & 7.9 & 0.359 & 613 & $1.1 \times 10^{4}$ & 1 \\
\hline 22 & Sennar & 5.93 & 8.9 & 8.2 & 0.424 & 620 & $2.4 \times 10^{4}$ & 2 \\
\hline 23 & Sennar & 6.38 & 8.5 & 8.0 & 0.323 & 560 & $1.5 \times 10^{4}$ & 4 \\
\hline 24 & Sennar & 6.83 & 8.7 & 7.9 & 0.402 & 557 & $2.0 \times 10^{4}$ & 3 \\
\hline 25 & Sennar & 6.26 & 8.7 & 7.9 & 0.323 & 585 & $2.0 \times 10^{4}$ & 1 \\
\hline 26 & Rahad & 6.95 & 8.8 & 7.8 & 0.543 & 700 & $1.5 \times 10^{4}$ & 1 \\
\hline 27 & Rahad & 10.37 & 8.5 & 7.7 & 0.477 & 641 & $1.5 \times 10^{3}$ & $\infty$ \\
\hline 28 & Rahad & 10.37 & 8.7 & 8.0 & 0.158 & 406 & $2.7 \times 10^{3}$ & $\infty$ \\
\hline 29 & Rahad & 8.93 & 8.0 & 7.4 & 0.101 & 333 & ND & 1 \\
\hline 30 & El Obeid & 8.93 & 6.6 & 5.9 & 0.082 & 322 & $3.0 \times 10^{2}$ & 1 \\
\hline 31 & El Obeid & 8.93 & 6.9 & 6.5 & 0.101 & 333 & $1.1 \times 10^{3}$ & 1 \\
\hline 32 & El Obeid & 10.13 & 6.8 & 6.1 & 0.946 & 1246 & $1.5 \times 10^{4}$ & $\infty$ \\
\hline
\end{tabular}

${ }^{a}$ Values are the average of 3 determinations. The moisture percentage is the moisture content at time of sampling, suspension $\mathrm{pH}$ was measured with a glass electrode at a soil: $\mathrm{H}_{2} \mathrm{O}$ ratio of $1: 5$, paste $\mathrm{pH}$ was measured in a saturated soil, organic carbon was measured by the Walkley-Black method, and organic nitrogen was measured by the Kjeldahl procedure.

${ }^{b}$ Populations are expressed on an oven-dry soil basis. The factor for determining $95 \%$ confidence limits is 4.68 (Cochran, 1950).

${ }^{c}$ Years since last planted to groundnut.

d $\infty=$ Never planted to groundnut.

ND $=$ Not determined.

dilution bottles at the Agricultural Research Corporation facilities at Wad Medani. One hundred, 3-mm dia glass beads were added, and each soil was shaken in a reciprocal shaker for $15 \mathrm{~min}$. Serial

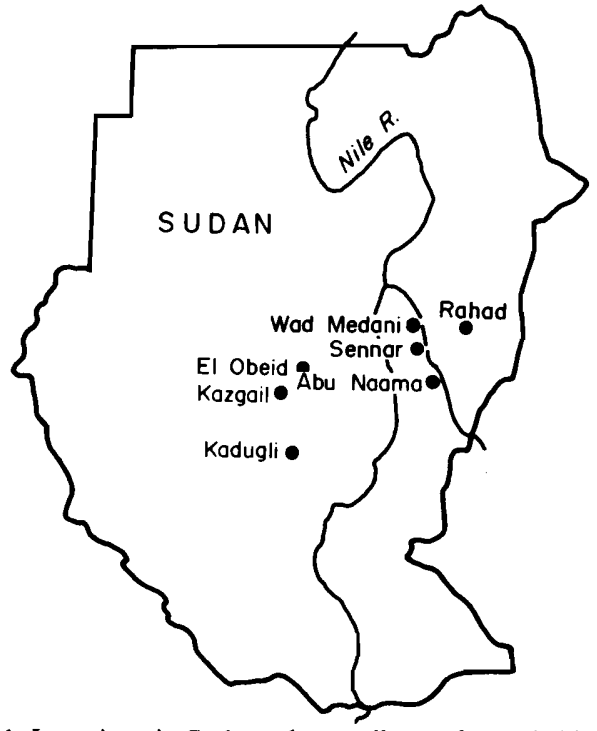

Fig. 1. Locations in Sudan where soil samples and rhizobial isolates were collected. dilutions were made to give $10^{-3}$ to $10^{-6}$. The siratro seeds were surface sterilized with $95 \%$ ethanol and $0.2 \% \mathrm{HgCl}_{2}$ acidified with $5 \mathrm{ml} \mathrm{HCl} \mathrm{l}^{-1}$, followed by five washes in sterile water. Three seeds were then transferred to each growth pouch (Scientific Products, Division of American Hospital Supply Corporation, Moline, Illinois), which had been steamed for $15 \mathrm{~min}$ with flowing steam. One $\mathrm{ml}$ of the proper dilution for each soil was aseptically added to each pouch and replicated three times. Twenty $\mathrm{ml}$ of a sterile complete nutrient solution lacking nitrogen was added through alcohol-washed plastic straws to allow bottom watering. The growth pouches in rack holders were transferred to an air-conditioned room where the temperature was maintained at $30^{\circ} \mathrm{C}$ with a 14-h photoperiod provided by overhead fluorescent lighting. Sterile water was added as required through the straws. The pouches were inspected for nodulation after 2 months growth. The data were compiled and analyzed by constructing a correlation matrix.

\section{Characterization of Sudanese rhizobia}

In the second part of the study, Rhizobium isolations were made by using procedures described by Vincent (1970) from nodules collected in August during the rainy season from the commonly grown 
Table 2. Legume of isolation and origin of the Rhizobium isolates used in the characterization study

\begin{tabular}{|c|c|c|c|}
\hline \multirow{2}{*}{$\begin{array}{c}\text { Isolate } \\
\text { no. }\end{array}$} & \multicolumn{2}{|c|}{ Legume of isolation } & \multirow[b]{2}{*}{ Origin" } \\
\hline & Common name & Scientific name & \\
\hline 1 & Mung bean & Vigna radiata & Central Sudan (Wad Medani) \\
\hline 2 & Pigeonpea & Cajanus cajan & Central Sudan (Wad Medani) \\
\hline 3 & Cowpea & Vigna unguiculata & Central Sudan (Wad Medani) \\
\hline 4 & Lubia & Dolichos lablab & Central Sudan (Wad Medani) \\
\hline 5 & Bambara groundnut & Voandezeia subterranea & Western Sudan (El Obeid) \\
\hline 6 & Groundnut & Arachis hypogaea & Central Sudan (Wad Medani) \\
\hline 7 & Groundnut & Arachis hypogaea & South central Sudan (Sennar) \\
\hline 8 & Groundnut & Arachis hypogaea & South central Sudan (Sennar) \\
\hline 9 & Groundnut & Arachis hypogaea & Western Sudan (Kazgail) \\
\hline 10 & Groundnut & Arachis hypogaea & Western Sudan (Kazgail) \\
\hline 11 & Groundnut & Arachis hypogaec & Western Sudan (Kadugli) \\
\hline 12 & 8A11 & - & $\begin{array}{l}\text { Supplied by the Nitragin } \\
\text { Company, Milwaukee, Wisconsin }\end{array}$ \\
\hline
\end{tabular}

Soils from central Sudan, south central Sudan, and Kadugli in western Sudan are classified as Vertisols; soils from El Obeid and Kazgail in western Sudan are classified as Alfisols.

legumes in Sudan (Table 2). The Kazgail and Kadugli sites (Fig. 1) were not sampled for Rhizobium counting in June, but nodules were collected in August. Colony characteristics were studied on yeast extract mannitol (YEM) agar medium containing bromthymol blue as a pH indicator. Growth in media with different $\mathrm{pH}$ 's, different sodium chloride levels and after moist-heat exposure followed the methods of Graham and Parker (1964). Mannitol and glucose utilization was tested at $28^{\circ} \mathrm{C}$ in basal mineral medium (YEM minus carbohydrate) in WheatonNephelo flasks placed on a waterbath shaker (140 rev $\min ^{-1}$ ). Daily changes in percentage transmittance were monitored with a spectrophotometer at $525 \mathrm{~nm}$.

Agglutination reactions were used to study the serological identity of the isolates. For antigen preparation, antiserum production, and agglutination reactions, the procedures described by Vincent (1970) were followed. A total of eleven isolates representing five legumes and four geographical locations within Sudan were tested for antigenic identity. Antisera developed for two groundnut isolates (Wad Medani and Kazgail) and a cowpea isolate were used for these tests. Readings were reported as strong agglutination (4), partial agglutination $(3,2,1)$, or no agglutinations $(0)$.

Infectivity and the relative efficiency of the isolates in fixing atmospheric nitrogen were determined under greenhouse conditions at Iowa State University by using the Sudanese groundnut cultivar "Barberton". Four-liter cans were fitted with autoclavable plastic bags, and a 1:1 (volume basis) sand-to-vermiculite mixture was added. Each can contained a glass tube extending to the bottom of the can through which water and nutrient solution were aseptically added. The glass tube was covered with a plastic Kaput to avoid direct dust contamination. Two hundred $\mathrm{ml}$ of complete nutrient solution lacking nitrogen was added for initial wetting of the cans. The cans and contents were sterilized for $4 \mathrm{~h}$ at $121^{\circ} \mathrm{C}$. Groundnut seeds were sterilized by immersing in $30 \% \mathrm{H}_{2} \mathrm{O}_{2}$ for $15 \mathrm{~min}$ followed by five rinses in sterile water. One seedling was aseptically transferred to each can, and $1 \mathrm{ml}$ of the proper Rhizobium suspension ( $>10^{6}$ rhizobia) was aseptically added. Sterile pea gravel was added to a depth of $0.5 \mathrm{~cm}$ to prevent surface contamination. A nitrogen control and an uninoculated control were included as treatment variables, and each treatment (Table 2) was replicated 4 times. The cans were positioned $60 \mathrm{~cm}$ apart in the greenhouse in a completely randomized design; positions were changed weekly. The temperature was regulated to give $30 \pm 2{ }^{\circ} \mathrm{C}$ with a 14-h photoperiod. After 2 months of growth, nodulation and tissue dry weights were evaluated as indicators of nitrogen fixation.

\section{RESULTS AND DISCUSSION}

Rhizobium abundance as influenced by soil characteristics

The soils sampled in June varied considerably in the properties measured (Table 1). Soil pH (paste) ranged from 5.9 to 8.5 . In general, the soils from central and south central Sudan were heavy clays (classified as Vertisols) and had neutral to alkaline $\mathrm{pH}$, and the soils from western Sudan were sands and had acid $\mathrm{pH}$. Also, the organic $\mathrm{C}$ content ranged from $0.08 \%$ for a sandy soil collected in western Sudan to a characteristic $0.3-0.4 \% \mathrm{C}$ for soils from central and south central Sudan. One exception was a soil from western Sudan that was collected under Hashab (Acacia senegal) seedlings and had $0.9 \%$ organic $\mathrm{C}$ and $1246 \mu \mathrm{g}$ organic $\mathrm{N} \mathrm{g}^{-1}$ soil.

The correlation coefficients indicated no obvious relationship between MPN counts and soil properties, or between MPN counts and the length of time since groundnuts were last in the rotation (Table 3 ). Counts of the native rhizobial population capable of nodulating siratro showed that most of the soils in Sudan harbor a large population of rhizobia that potentially can nodulate groundnuts. Rhizobia were found in sites never planted to groundnuts (Table 1). With the exception of a sandy soil from western Sudan that contained fewer than 300 rhizobia $\mathrm{g}^{-1}$ (lowest detection level of the test), 5 soils never before planted to groundnuts contained an average of $4.9 \times 10^{5}$ rhizobia $\mathrm{g}^{-1}$; one of the samples had $2.4 \times 10^{6}$ rhizobia $g^{-1}$. This compares with averages of $2.3 \times 10^{5}, 3.6 \times 10^{4}, 2.9 \times 10^{4}$ and $3.7 \times 10^{4}$ rhizobia $\mathrm{g}^{-1}$ obtained from soils last planted to groundnuts $1,2,3$ and 4 years before sampling, respectively. Groundnut is the only legume commonly included in cultivated rotations in Sudan. Either rhizobia are naturally part of the indigenous soil population or native legumes (predominantly Acacia sp.) are serving as an inoculant source in 
Table 3. Correlation coefficients $(r)$ between soil characteristics and groundnut-nodulating rhizobia

\begin{tabular}{|c|c|c|c|c|c|c|c|}
\hline \multirow[b]{2}{*}{ Parameter } & \multirow[b]{2}{*}{ Moisture } & \multicolumn{2}{|c|}{$\mathrm{pH}$} & \multirow{2}{*}{$\begin{array}{c}\text { Organic } \\
\text { carbon }\end{array}$} & \multirow{2}{*}{$\begin{array}{c}\text { Total } \\
\text { nitrogen }\end{array}$} & \multirow[b]{2}{*}{ MPN } & \multirow[b]{2}{*}{ Years $^{a}$} \\
\hline & & Suspension & Paste & & & & \\
\hline Moisture & & -0.10 & -0.20 & -0.12 & 0.08 & 0.11 & -0.02 \\
\hline $\mathrm{pH}$ (suspension) & & & $0.94 * *$ & 0.11 & 0.12 & 0.29 & 0.14 \\
\hline $\mathrm{pH}$ (paste) & & & & 0.04 & 0.05 & 0.16 & 0.13 \\
\hline Organic carbon & & & & & $0.96 * *$ & 0.11 & 0.18 \\
\hline Total nitrogen & & & & & & 0.08 & 0.14 \\
\hline MPN & & & & & & & -0.19 \\
\hline
\end{tabular}

Years since last planted to groundnut.

**Significant at the 0.01 level of probability.

Sudan for rhizobia of the cowpea miscellany. The numbers of rhizobia in surface soil capable of nodulating siratro were higher in this study than those reported earlier from two soils in northern Nigeria, although Day et al. (1978) reported numbers to increase dramatically with increasing depth in the Nigerian soils.

\section{Cultural and physiological characteristics}

All the isolates tested were short, Gram-negative rods. The colonies were circular with entire margins and with raised to convex elevations. Though all the isolates tested were slow growers, some differences were evident. For example, isolates from lubia, bambara groundnut, groundnut (Kadugli) and pigeonpea could be placed in a group based on their first appearance on YEM-agar plates in 12 days and reaching a colony size of $<1.0 \mathrm{~mm}$ in 14 days. The isolates from groundnut (Sennar) and the mung bean isolate appeared on plates in 10 days and reached a colony size of $1.0 \mathrm{~mm}$ in 14 days. The final group is represented by the Wad Medani strain, Sennar, and the Kazgail isolates (groundnut), which appeared on plates in 10 days and reached a colony size of $>1.0 \mathrm{~mm}$ in 14 days of growth at $28^{\circ} \mathrm{C}$.

Eight of 11 strains survived the moist-heat treatment for $15 \mathrm{~min}$ at $50^{\circ} \mathrm{C}$. Graham and Parker (1964) reported no survival after this treatment, but Habish and Kheiri (1968) did report survival of some cowpea miscellany isolates.

Utilization of glucose and mannitol was similar except that the isolate from lubia utilized mannitol somewhat less efficiently than glucose. Was this related to less growth or less polysaccharide production from mannitol-grown cells? In a further experiment where cells were washed free of polysaccharide with phosphate buffered saline $\left(5.6 \mathrm{~g} \mathrm{Na} \mathrm{NPO}_{4}, 2.7 \mathrm{~g}\right.$ $\mathrm{KH}_{2} \mathrm{PO}_{4}$, and $4.1 \mathrm{~g} \mathrm{NaCl}^{-1}$ adjusted to $\mathrm{pH} 7.2$ ), and counted with a cell counter, results were similar to those without cell washing.

None of the strains grew at $\mathrm{pH} 4$ and 10 , but they did grow at pH 6 and 8. Isolates could not be differentiated by their relative rates of growth in media adjusted to the wide range of acidities tested.

\section{Infectiveness of the isolates}

All the isolates tested nodulated siratro and groundnut. This is at variance with the results of Habish and Kheiri (1968) who reported that groundnuts were not nodulated by isolates from cowpea, pigeonpea and lubia. The groundnut isolate from Medani gave a total of 161 nodules per plant, while the isolate from pigeonpea gave only five nodules per plant (Table 4). The two groundnut isolates from
Sennar (trts 7 and 8) and one isolate from Kazgail (trt 9) gave a relatively low number of nodules, suggesting that these strains were not as infective as other groundnut isolates.

The infectiveness of the isolates in forming nodules varied within as well as among locations. Whereas one isolate from Kazgail (western Sudan) gave 107 nodules per plant, the other isolate from the same field produced significantly $(P<0.05)$ fewer nodules (48 nodules per plant). Based on these nodulation results, it is justifiable to classify all the tested rhizobia as belonging to the cowpea miscellany.

\section{Nitrogen fixation}

Wynne et al. (1980) reported that nodulation, plant weight, nitrogenase activity and $\mathbf{N}$ content of greenhouse-grown groundnut were significantly correlated with each other. The isolated rhizobia in this study varied significantly in the number of nodules and top dry weights produced (Table 4 ). The groundnut isolate from Medani (trt 6) produced significantly more nodules than the other isolates, including the standard strain 8A11, but most of the nodules in this treatment had white interiors, and approximately $90 \%$ were small and located on lateral roots. The greater number of nodules did not result in greater top dry weights. Other groundnut isolates that produced many nodules were Kazgail (trt 10) and Kadugli (trt 11). The nodules of these isolates were mostly located on the main root, had red interiors, and were associated with large top dry weights. These results agree with those of Bromfield and Roughley (1980),

Table 4. Nitrogen-fixation traits of groundnut after inoculation with Sudanese Rhizobium isolates

\begin{tabular}{|c|c|c|c|}
\hline Treatment & Isolate & $\begin{array}{c}\begin{array}{c}\text { Nodules }^{\mathrm{a}} \\
\text { (no. plant }\end{array}{ }^{-1} \text { ) } \\
\end{array}$ & $\begin{array}{c}\text { Top dry } \\
\text { weight }^{\mathrm{a}} \\
\left.\text { (g plant }^{-1}\right)\end{array}$ \\
\hline 1 & Mung bean & $54.0 \mathrm{def}$ & $0.62 \mathrm{ab}$ \\
\hline 2 & Pigeonpea & $5.0 \mathrm{~g}$ & $0.53 \mathrm{ab}$ \\
\hline 3 & Cowpea & $62.3 \mathrm{cde}$ & $0.40 \mathrm{~b}$ \\
\hline 4 & Lubia & 31.3efg & $0.57 \mathrm{ab}$ \\
\hline 5 & Bambara groundnut & 93.3bcd & $0.68 \mathrm{ab}$ \\
\hline 6 & Groundnut (Wad Medani) & $161.3 \mathrm{a}$ & $0.61 \mathrm{ab}$ \\
\hline 7 & Groundnut (Sennar) & 36.0efg & $0.42 b$ \\
\hline 8 & Groundnut (Sennar) & $19.0 \mathrm{fg}$ & $0.41 b$ \\
\hline 9 & Groundnut (Kazgail) & $48.3 \mathrm{ef}$ & $0.46 \mathrm{ab}$ \\
\hline 10 & Groundnut (Kazgail) & $107.0 \mathrm{~b}$ & $0.67 a b$ \\
\hline 11 & Groundnut (Kadugli) & $109.7 \mathrm{~b}$ & $0.82 \mathrm{a}$ \\
\hline 12 & $8 \mathrm{~A} 11$ & $95.0 \mathrm{bc}$ & $0.60 \mathrm{ab}$ \\
\hline 13 & Uninoculated control & $0.0 \mathrm{~g}$ & $0.58 \mathrm{ab}$ \\
\hline 14 & Nitrogen control & $1.0 \mathrm{~g}$ & $0.81 \mathrm{a}$ \\
\hline
\end{tabular}

Values represent an average of 4 replications; means within the same column having a common letter are not significantly different at the 0.05 level of probability by the Duncan Multiple-Range Test. 
Table 5. Serological cross reactivity of rhizobia isolated from different legumes and different locations in Sudan

\begin{tabular}{lccc}
\hline & \multicolumn{3}{c}{ Antiserum } \\
\cline { 2 - 4 } \multicolumn{1}{c}{ Antigen } & $\begin{array}{c}\text { Groundnut } \\
\text { (Wad Medani) }\end{array}$ & $\begin{array}{c}\text { Groundnut } \\
\text { (Kazgail) }\end{array}$ & Cowpea \\
\hline Groundnut (Wad Medani) & $4^{\mathrm{a}}$ & 4 & 4 \\
Groundnut (Kazgail) & 1 & 4 & 2 \\
Groundnut (Kazgail) & 0 & 0 & 0 \\
Groundnut (Sennar) & 4 & 2 & 2 \\
Groundnut (Sennar) & 2 & 0 & 0 \\
Groundnut (Kadugli) & 0 & 0 & 0 \\
Cowpea & 4 & 2 & 4 \\
Green gram & 0 & 4 & 4 \\
Pigeonpea & 1 & 0 & 4 \\
Lubia & 0 & 0 & 0 \\
Bambara groundnut & 0 & 0 & 0 \\
\hline
\end{tabular}

a Reactivity was evaluated by agglutination with $4=$ strong agglutination, 3, 2, $1=$ partial agglutination, and $0=$ no agglutination

who worked with cowpea miscellany isolates from Nigeria, in that the isolates varied in their nitrogen fixation efficiency but, in this study, differences among isolates in top dry weights generally were small. This perhaps was related to the lack of robustness of the Sudanese cultivar used in the tests.

\section{Serological identity of the isolates}

Several of the groundnut rhizobia reacted with antisera produced from isolates from Medani, Kazgail and the cowpea isolate (Table 5). Cross reactivity was found and several of the strains evidently had common antigenic sites leading to partial agglutination. Four isolates failed to react with any of the tested antisera.

This was an initial attempt, based on a limited sampling, to characterize Sudanese rhizobial isolates. Cowpea-type rhizobia obviously vary at different locations, and alternate hosts are capable of providing rhizobia that can nodulate groundnut. Rhizobial numbers in the soil were not related to measured soil properties or to the length of time since groundnut was last planted.

Acknowledgements - This is Journal Paper No. J-11400 of the Iowa Agriculture and Home Economics Experiment Station, Ames, Project 2420. This research was partly supported by a USDA/SEA-CR grant.

\section{REFERENCES}

Ahmed M. H., Eaglesham A. R. J., Hussouna S., Seaman B., Ayanaba A., Mulongoy K. and Pulver E. L. (1981)
Examining the potential for inoculant use with cowpea in West African soils. Tropical Agriculture 58, 325-335.

Bezdicek D. F. (1972) Effects of soil factors on the distribution of Rhizobium japonicum serogroups. Soil Science Society of America Proceedings 36, 305-307.

Bromfield E. S. P. and Roughley R. J. (1980) Characterization of rhizobia isolated from nodules on locally adapted Glycine max grown in Nigeria. Annals of Applied Biology 95, 185-190.

Buchanan R. E. and Gibson N. E. (Co-eds) (1974) Bergey's Manual of Determinative Bacteriology, 8th edn, pp. 263-264. Williams \& Wilkins, Baltimore.

Cochran W. G. (1950) Estimation of bacterial densities by means of the most probable number. Biometrics 6, 105-116.

Damirgi S. M., Frederick L. R. and Anderson I. C. (1967) Serogroups of Rhizobium japonicum in soybean nodules as affected by soil types. Agronomy Journal 59, 10-12.

Day J. M., Roughley R. J., Eaglesham R. J., Dye M. and White S. P. (1978) Effect of high soil temperatures on nodulation of cowpea, Vigna unguiculata. Annals of Applied Biology 88, 476-481.

Fred E. B., Baldwin L. L. and McCoy E. (1932) Root Nodule Bacteria and Leguminous Plants. University of Wisconsin Studies in Science, Madison.

Graham P. J. and Parker C. A. (1964) Diagnostic features in the characterization of the root-nodule bacteria of legumes. Plant and Soil 28, 383-395.

Habish H. M. and Kheiri Sh. M. (1968) Nodulation of legumes in the Sudan: Cross inoculation groups and the associated Rhizobium strains. Experimental Agriculture 4, 227-234.

Nambiar P. T. C. and Dart P. J. (1982) Response of groundnut (Arachis hypogaea L.) to Rhizobium inoculation. Technical Report 1. International Crops Research Institute for the Semi-Arid Tropics, Patancheru, India.

Vincent J. M. (1970) A Manual for Practical Study of Root-Nodule Bacteria. International Biological Programme, Handbook No. 15. Blackwell, Oxford.

Weaver R. W. and Frederick L. R. (1972) A new technique for most probable number count of rhizobia. Plant and Soil 36, 219-222.

Weaver R. W., Frederick L. R. and Dumenil L. C. (1972) Effect of soybean cropping and soil properties on numbers of Rhizobium japonicum in Iowa soils. Soil Science 114, 137-141.

Wynne J. C., Elkan G. H. and Schneeweis T. J. (1980) Increasing nitrogen fixation of the groundnut by strain and host selection, pp. 95-109. Proceedings of the International Workshop on Groundnuts. International Crops Research Institute for the Semi-Arid Tropics, Patancheru, India.

Zablotowicz R. M. and Focht D. D. (1981) Physiological characteristics of cowpea rhizobia: Evaluation of symbiotic efficiency in Vigna unguiculata. Applied and Environmental Microbiology 41, 679-685. 